\title{
Cytokine Status in Game Sports Athletes with Cardiomyopathy of Overstrain
}

\author{
Vladimir Vasilenko ${ }^{1}$, Zakhar Lopatin ${ }^{1}$ and Evgeniy Kopylov ${ }^{2 *}$ \\ ${ }^{1}$ Saint-Petersburg State Pediatric Medical university, department of Hospital Header with course of endocrinology, Russia \\ ${ }^{2}$ North-Western state medical university named after I.I. Mechnikov, Russia
}

*Corresponding author: Kopylov Evgeniy Dmitrievich, North-Western State medical university named after I.I. Mechnikov, SaintPetersburg, 191015, Kirochnaya ul. 41. Russia

\section{ARTICLE INFO \\ Received: 㓞 September 18, 2019 \\ Published: 幽 September 25, 2019}

Citation: Vladimir Vasilenko, Zakhar Lopatin, Evgeniy Kopylov. Cytokine Status in Game Sports Athletes with Cardiomyopathy of Overstrain. Biomed J Sci \& Tech Res 21(4)-2019. BJSTR. MS.ID.003622.

\begin{abstract}
Cytokines are the group of the hormone - like peptides and proteins, which are synthesized and secreted by immune cells. These molecules have an enormous influence on biochemical processes in organisms taking part in inflammation, differentiation and cell maturation. Imbalance of cytokines may be the cause of pathological changes in different systems of organs.
\end{abstract}

Keywords: Cytokines; Cardiomyopathy of overstrain; Sport

\section{Introduction}

The regular intensive physical psycho-emotional loads are characteristic for modern sport. They lead to organism's changes that affect most organs, systems and biochemical processes. The cardiovascular system is most affected [1,2]. Imbalance in cytokine status have a significant role in pathological changes in cardiovascular system. Pro-inflammatory cytokines are markers not only of risk of atherosclerosis, but also indicators of overstrain of heart during the inadequate physical loads $[3,4]$.

\section{Results}

Comparing athletes without cardiovascular pathology and sportsmen with process of repolarization disruption(PRD) of $2-3$ stages it is revealed that level of pro-inflammatory IL-1 $\beta$ and IL-8 is higher in the last ones $(52,1 \pm 14,0$ and $16,6 \pm 2,5 \mathrm{pg} / \mathrm{ml}$ against $296,3 \pm 111,1$ and $110,8 \pm 33,0 \mathrm{pg} / \mathrm{ml}$ at $\mathrm{p}<0,05-0,01)$. The lowest level of anti-inflammatory IL-4 is also registered in athletes with PRD $(2,0 \pm 1,0$ against $7,1 \pm 2,3 \mathrm{pg} / \mathrm{ml}$ at $\mathrm{p}<0,05)$. All defined interleukins, including IL-8(in the united group it was isolated), in sportsmen with electrocardiographic signs of cardiomyopathy of overstrain (PRD and rhythm disturbance) are linked by positive correlation ( $\Gamma$ from 0,58 to 0,98 ). TNF- $\alpha$, IL-1 $\beta$,
IL-4 have also a positive correlation ( $\Gamma$ from 0,42 to 0,61 ) with CPK-MB what indicates not only a connection TNF- $\alpha$ and IL- $\beta$ with destruction of the cardiomyocytes, but also compensatory rising of anti-inflammatory IL-4. The most significant correlation is revealed between TNF- $\alpha$ and CPK-MB $(\Gamma=0,61)$. It confirms opinion about role of TNF- $\alpha$ in progress of myocardial dysfunction $[5,6]$.

\section{Conclusion}

In research it is found that athletes with signs of myocardial dystrophy regarding sportsmen without cardiovascular pathology have a high level of IL-1 $\beta$ and IL-8. Substantial correlation $(\Gamma=0,61)$ between TNF- $\alpha$ and CPK-MB in athletes with myocardial dystrophy of overstrain confirms the role of TNF- $\alpha$ in progress of myocardial dysfunction. The most severe problems are found in sportsmen with myocardial dystrophy of overstrain are detected on ECG(PRD of 2-3 stages).

\section{References}

1. Opal SM, DePalo VA (2000) Anti-inflammatory cytokines. Chest 117(4): $1162-1172$

2. Chelko SP, Asimaki A, Lowenthal J, Bueno-Beti C, Bedja D, et al. (2019) Therapeutic Modulation of the Immune Response in Arrhythmogenic Cardiomyopathy Circulation. 
3. Lima BB, Hammadah M, Kim JH, Uphoff I, Shah A, et al. (2019) Association of Transient Endothelial Dysfunction Induced by Mental Stress with Major Adverse Cardiovascular Events in Men and Women with Coronary Artery Disease. JAMA Cardiol pp. 3252.

4. Peter Libby, Karin Bornfeldt, Alan R Tall (2017) Atherosclerosis: Successes, Surprises, and Future Challenges. Circ Res 118(4): 531-534.
5. Dal LinC, Poretto A, Scodro M, Marra MP, Iliceto S, et al. (2015) Coronary microvascular and endothelial function regulation: crossroads of psych neuroendocrine immunitary signals and quantum physics. Journal of Integrative Cardiology pp. 132-163.

6. Sattler S, Kennedy-Lydon T (2017) The Immunology of Cardiovascular Homeostasis and Pathology. Springer.

\section{ISSN: 2574-1241}

DOI: 10.26717/BJSTR.2019.21.003622

Evgeniy Kopylov. Biomed J Sci \& Tech Res

This work is licensed under Creative Commons Attribution 4.0 License

Submission Link: https://biomedres.us/submit-manuscript.php

\begin{tabular}{ll} 
BIOMEDICAL & Assets of Publishing with us \\
RESEARCHES & - Global archiving of articles \\
- Immediate, unrestricted online access & - Rigorous Peer Review Process \\
\hline
\end{tabular}

